rather extensive areas, the one on Mt. Waialeale covering several square miles.

Three species of tree ferns are found on the islands, and in some places form extensive forests. These plants produce at the base of the stipe a great ball of brownish-yellow wool called pulu by the natives, and used by them for stuffing pillows and mattresses.

\section{HIGHER EDUCATION IN THE UNITED STATES.}

THE report of the U.S. Commissioner of Education for the year ended June 30 , I9r6, has been received from Washington. It consists of two bulky volumes, one running to 692 pages and the other to 663 pages. The first part contains a comprehensive survey of the progress of education in the United States for the school year $19^{1} 5^{-16}$, and also a similar account of educational progress in all those foreign countries from which the U.S. Bureau of Education could obtain sufficient information. The second volume is given up to educational statistics, but owing to the difficulty of compiling such a mass of data and the time absorbed in the task, the numbers provided deal only with the year I9I4-I5.

\section{The Cost of American Education.}

The estimated cost of education in the United States in 1914 was very nearly $160,000,000 \%$. An estimate, making due allowances for the time which has elapsed since the date given, would easily bring the current educational expenditure in the States to $200,000,000 l$. Public elementary schools cost approximately I00,000,00ol.; public high schools, $x_{4}, 000,000 l$; private elementary schools, I0,400,oool.; private secondary schools, 3,00o oool.; universities, colleges, and professional schools, 20,00o,oool.; and normal schools, $3,000,000 l$.

\section{Gifts and Bequests.}

The Bureau of Education periodically publishes tabular statements showing the amounts of gifts and bequests to education. The total for 1914 reached $6,27 \mathrm{I}, 490 l$., the greatest ever recorded for a single year. For the academic year $19 \mathrm{r}_{4}-\mathrm{I}_{5}$ the total amount received in this way was $4,062,050 l$.; and of this about $\mathrm{I}, 997,000 l$. was for increase of plant, $7 \mathrm{Ir}, 300 \mathrm{l}$. for current expenses, and $2, \mathrm{I}_{53}, 800 \mathrm{l}$. for endowment. Thirty-five universities, colleges, and technological schools reported gifts of more than $20,000 l$, the total amount received by these institutions reaching $2,987,160 l$. The following institutions each received more than roo,oool. :-Johns Hopkins University, 27 I,82ol.; Wellesley College, 255,585l.; Harvard University, 244,oool. ; University of Pennsvlvania, 234,70ol.; University of Chicago, 228,876l.; Yale University, $193,160 l$.; Princeton University, $157,909 l$.; and Massachusetts Institute of Technology, ${ }_{155,453 l \text {. }}$

The generous benefactions received for education in the States during 185 were distributed among the various classes of educational institutions as follows :-

\begin{tabular}{|c|c|c|c|}
\hline & & & \\
\hline Universities and colleges & $\cdots$ & $\cdots$ & 5,334 , O IO \\
\hline Schools of theology $\ldots$ & $\cdots$ & $\cdots$ & $3 \mathrm{II}, 660$ \\
\hline Schools of law $\quad \ldots$ & $\ldots$ & $\ldots$ & 40,610 \\
\hline Schools of medicine ... & $\ldots$ & $\ldots$ & 299,150 \\
\hline Public normal schools & ... & ... & 121,490 \\
\hline Private normal schools & $\cdots$ & ... & 23,26 \\
\hline Private high schools ... & $\ldots$ & $\ldots$ & 141,31 \\
\hline
\end{tabular}

For the forty-four years from I87I to I9I4 inclusive the grand total of gifts and bequests to American education reaches $116,88_{3}, 6167$.

\section{Number of Students.}

For the year ending June, I9I5, the U.S. Bureau of Education received reports from 563 universities, colleges, and technological schools in the different States. States and municipalities control ninety-five of these institutions, and private corporations control 468 . There were 237,168 students in the collegiate and resident graduate departments of these institutions, and of this total $84,86 \mathrm{r}$ were women.

In the year $1915,29,608$ baccalaureate, 4I 40 graduate, and 883 honorary degrees were conferred. The degree of doctor of philosophy was conferred on examination by forty-three institutions on 486 men and 60 women.

\section{Agricultural and Mechanical Colleges.}

The institutions commonly known as "agricultural and mechanical colleges," or "land-grant colleges," are dealt with in a separate chapter of the seport. In some States, it should be remembered, the agricultural and mechanical colleges form parts of the State universities, and in such cases the statistics respecting such universities concern themselves also with the activities of these departments

During I9I4-I 5 particulars respecting sixty-nine agricultural and mechanical colleges were collected by the bureau. In the fifty-two institutions for white students there were 9742 instructors of various grades, and in the seventeen institutions exclusively for coloured students there were 529 instructors. The total number of students in these institutions was 125,075 .

The total income of these colleges for I9I5 was $6,392,353 l$., of which $3,601,221 l$. was State and the remainder Federal aid. In addition, the colleges received the following grants for the year:-U.S. grant for experiment stations, $273,858 \mathrm{l}$. ; State grants for experiment stations, 225,942l.; State grants for extension work and farmers' institutes, 215,oorl. ; and U.S. grant for extension work, $98,248 l$. The distribution, according to source, excluding the experiment station funds and the extension and farmers' institute funds, was Federal government II per cent., State 56 per cent., and private funds 33 per cent.

\section{UNIVERSITY AND EDUCATIONAL INTELLIGENCE.}

THE inaugural address for the session 1917-18 of the London (Royal Free Hospital) School of Medicine for Women will be delivered by Dr. L. Garrett Anderson, C.B.E., on Monday, October I, at $3.30 \mathrm{p} . \mathrm{m}$. The subject will be "Ambition."

Mention was made in Nature of May i7 (p. 238) of a bequest by the late Mrs. E. D. Denning, of South Norwood, of property for the application of modern scientific knowledge to educational needs. It is now announced in the Times (September I8) that Mrs. Denning left estate of the gross value of $x 69,7 \mathrm{Igl}$., the net personalty being $78,58 \mathrm{rl}$. By her will she bequeathed "to the Public Trustee all her freehold property in trust for a 'Frank Denning Memorial' for the advancement and propagation of education in mechanical science in any part of the United Kingdom, with preference to those persons who reside in the Borough of Croydon."

A Secondary-School Examinations Council has been constituted by the President of the Board of Education to assist the Board in the co-ordination of the examinations to which secondary schools now submit their pupils. The council is to consist in the first instance of the following representative members, with the Rev. William Temple, formerly headmaster of Repton School, as chairman :- Oxford and Cambridge Schools Examination Board, Mr. P. E. Matheson; Oxford Delegacy for Local Examinations, Mr. H. T. Gerrans;

NO. 2499, VOL. IOO] 